DOI: https://doi.org/10.25217/jcd.v1i2.1833 | Accepted 26'Agus 2021 | Published 30'Sept 2021

\title{
Development of Children's Ability to Recognize Letters Through Unscrambled Words at BIAS Kindergarten Yogyakarta
}

\author{
Adin Suryadin \\ adinstait@gmail.com \\ STAI Terpadu Yogyakarta \\ Rz. Ricky Satria Wiranata \\ rickysatriawiranata@gmail.com \\ STAI Terpadu Yogyakarta \\ M. Sayyidul Abrori \\ arori400@gmail.com \\ Institut Agama Islam Ma'arif NU (IAIMNU) Metro Lampung
}

\begin{abstract}
The development of children's ability to recognize letters at the beginning of entering the B1 kindergarten class is still low. The purpose of this study was to improve children's ability to recognize letters through word deciphering games. The research method used is classroom action research, with the research subject of the BI group at the Integrated Islamic Kindergarten of Bina Anak Sholeh Yogyakarta. The technique in collecting data is in the form of observation, which is processed by the percentage technique. The results of the research in each cycle have shown an increase in the ability of children to recognize letters from the initial conditions, cycle I to cycle I. Thus it can be concluded that word deciphering games can improve children's ability to recognize letters.
\end{abstract}

Keywords: Recognizing Letters, Children, Deciphering Words

\section{INTRODUCTION}

Taman Kanak-kanak merupakan salah satu lembaga alur pendidikan formal yang menyelenggarakan program pendidikan bagi anak usia empat tahun sampai enam tahun (Purnamasari et al., 2014). Sesuai dengan tujuan TK menurut undangundang Republik Indonesia No. 20 Tahun 2003 Tentang sistem Pendidikan Nasional I BAB VI pasal 28 ayat 3 berbunyi : "Pendidikan anak usia dini pada jalur pendidikan formal berbentuk Taman Kanak-kanak, Raudatul Athfal atau bentuk lain yang sederajat". Dalam Pendidikan, guru sangat memaikan peran penting dalam pengetahuan kepada anak didik (Fauzia, 2018).

Pendidikan Taman Kanak-kanak salah satu bentuk Pendidikan Anak Usia Dini pada jalur Pendidikan Formal yang menyediakan program pendidikan bagi 
anak usia 4 sampai 6 tahun. Usia 4 sampai 6 tahun ini merupakan usia yang paling efektif untuk mengembangkan berbagai potensi yang di miliki anak. Menurut Muliawan, pendidikan anak usia dini atau yang sering disingkat paud adalah pendidikan yang diberikan kepada anak usia dua sampi enam tahun. Pendidikan anak usia dini disebut juga dengan pendidikan anak prasekolah, taman bermain, atau taman kanak-kanak (Muliawan, 2009).

Pendidikan di Taman Kanak-kanak sangat penting dalam kehidupan seorang anak, karena pendidikan saat ini sebagai modal dasar untuk perkembangan selanjutnya. Selain itu, proses pembeljaran merupakan model utama dalam melaksanakan Pendidikan formal (Rohim \& Susanto, 2012). Untuk itu pembelajaran di TK haruslah di sesuaikan dengan perkembangan anak dan memberikan rasa aman, nyaman, menyenangkan dan menarik bagi anak serta mendorong keberanian. Dalam PP RI No.19 Tahun 2005 tentang standar pendidikan Bab. IV Pasal 19 dinyatakan bahwa: proses pembelajaran pada satuan pendidikan diselenggarakan interaktif, menyenangkan, menantang,memotivasi, peserta didik untuk berpartisipasi aktif serta memberikan ruang yang cukup bagi prakarsa, kreatifitas dan kemandirian sesuai dengan bakat dan perkembangan fisik dan psikologi peserta didik.

Pendidikan di Taman Kanak-kanak bertujuan untuk membantu anak didik mengembangkan berbagai potensi baik psikis dan fisik yang meliputi moral dan nilai agama, sosial, emosional, kemandirian, kognitif, bahasa, fisik/motorik dan seni untuk siap memasuki sekolah dasar. Masa usia Taman Kanak-kanak merupakan masa emas, dimana perkembangan fisik, mptorik, kognitif, bahasa, sosial, emosional anak berkembang dengan sangat cepat. Untuk mencapai perkembangan anak tersebut dilakukan dalam kegiatan pembelajar. Kegiatan pembelajaran di Taman Kanak-kanak lebih dikenal sebagai kegiatan bermain.

Dunia anak-anak adalah bermain. Bermain merupakan cara yang paling baik untuk mengembangkan potensi yang ada pada anak. Bermain juga salah satu pendekatan pembelajaran di Taman Kanak-kanak. Hal ini sesuai dengan prinsip belajar Taman Kanak-kanak yaitu bermain sambil belajar, belajar seraya bermain. Menurut Sudono bermainadalah suatu kegiatan yang dilakukan dengan atau tanpa menggunakan alat yang menghasilkan pengertian atau memberikan informasi, memberikan rangsangan maupun mengembangkan imajinasi pada anak. Melalui pembelajaran di Taman Kanak-kanak diharapkan mampu mengembangkan aspekaspek perkembangan anak sesuai dengan kurikulum Taman Kanak-kanak tahun 2010 yaitu : 1). Nilai-nilai agama dan moral, 2). Fisik, 3). Kognitif, 4). Bahasa (Depdiknas, 2000b).

Anak Taman Kanak-kanak pada umumnya sudah mampu berkomunikasi secara lisan, namun untuk membaca anak masih mengalami kesulitan mengingat bahasa merupakan sistem yang rumit dan melibatkan berbagai unsur seperti huruf (simbol), kata, kalimat dan tata cara melafalkannya. Untuk mengembangkan kemampuan membaca pada anak, guru harus mampu menciptakan media berupa alat permainan yang memotivasi anak dalam belajar. Media yang digunakan dibuat bervariasi agar anak tidak merasa bosan dan jenuh dalam belajar (Depdiknas, 1995).

Namun pada kenyataannya yang peneliti amati dilapangan, guru belum mampu mengembangkan ide-ide yang dapat mengembangkan aspekaspek 
perkembangan anak dalam kegiatan pembelajaran. Terutama pada aspek membaca mengenal huruf, dimana cara guru mengenalkan huruf pada anak langsung menyebutkan bunyi huruf sambil menunjuk huruf kemudian cenderung memberikan kegiatan berupa penugasan bentuk lembaran kerja. Sebagai seorang guru peneliti menyadari bahwa cara mengajar guru yang seperti ini mengakibatkan kemampuan anak mengenal huruf masih rendah dan cara pengucapannya juga kurang jelas, anak kurang bisa membedakan bentuk huruf sehingga sulit menanamkan konsep kata pada anak. Metode dan alat atau media yang digunakan guru kurang bervariasi sehingga anak merasa bosan dan jenuh dalam belajar.

Salah satu aspek pengembangan kemampuan dasar anak yaitu : Bahasa. Kemampuan berbahasa sangatlah perlu di kembangkan karena dengan berbahasa anak dapat memahami kata dan kalimat serta memahami hubungan antara bahasa lisan dan tulisan pra-membaca awal. Pengembangan kemampuan bahasa ini bertujuan agar anak mampu mengungkapkan pikiran melalui bahasa yang sederhana secara tepat, mampu berkomunikasi secara efektif dan membangkitkan minat anak untuk dapat berbahasa Indonesia. Selain Bahasa, anak belajar mengasah keterampilan sosial dan keterampilan berbicara di sekolah sehingga memiliki kepribadin yang matang saat dewasa (Siska, 2011).

Untuk mencapai tujuan pengembangan bahasa pada anak di perlukan tenaga pendidik yang propesional yaitu guru. Guru yang propesional adalah guru yang memiliki keterampilan, pengetahuan secara utuh, tidak saja melibatkan orang, tempat, benda-benda di samping pengetahuan keguruan, tetapi juga ide-ide kreatif dalam menggunakan dan merancang alat permainan yang menantang bagi anak, karena sesungguhnya anak merupakan subjek yang dikembangkan karena masih polos dan memeliki potensi (Astria et al., 2015). Selain itu, anak dini juga mememiliki kemampuan tumbuh kembang secara alami, sehingga mudah dalam mengarahkannya (Ardyatmika et al., 2016).

Peranan guru sangat penting dalam pengembangan bahasa anak, untuk mengembangkan kemampuan berbahasa anak Taman Kanak-kanak, dapat diarahkan melalui komponen berbahasa yaitu: menyimak, membaca, menulis dan berbicara. Salah satu komponen berbahasa adalah membaca. Mengajarkan membaca di Taman Kanak-kanak dapat dilaksanakan selama dalam batasbatas aturan pengembangan pra-sekolah atau pra akademik serta mendasarkan diri pada prinsip dasar hakiki dari pendidikan Taman Kanakkanak sebagai sebuah taman bermain (Depdiknas, 2000).

Berdasarkan uraian latar belakang di atas, maka peneliti dapat mengidentifikasikan permasalahan sebagai berikut 1 . Kemampuan anak dalam mengenal huruf masih rendah. 2. Anak kurang bisa dalam membedakan huruf sehingga sulit menanamkan konsep kata kepada anak 3. Metode dan alat yang digunakan Guru kurang bervariasi. Sebagai mana identifikasi masalah yang telah di kemukakan, maka peneliti membatasi permasalahan dalam hal rendahnya kemampuan anak mengenal huruf di TKIT Bina Anak Sholeh Yogyakarta.

Berdasarkan masalah di atas dapat di rumuskan sebagai berikut: "Bagaimana permainan menguraikan kata dapat meningkatkan kemampuan anak mengenal huruf di TKIT Bina Anak Sholeh Yohyakarta. Rancangan pemecahan masalah 
dalam penelitian ini adalah dengan melalui permainan menguraikan kata untuk meningkatkan masalah rendahnya kemampuan anak dalam mengenal huruf.

Adapun tujuan penelitian ini adalah untuk meningkatkan kemampuan anak dalam mengenal huruf melalui permainan mengurai kata di TKIT Bina Anak Sholeh Yogyakarta. Mengenal huruf dalam teori whole language dalam Susanto yaitu anak belajar mengenali huruf dan bunyinya dari konteksnya ( dari bahasa yang digunakan ). Misalnya guru bertanya sama anak siapa namanya anak menjawab "ani" kemudian guru bertanya lagi bunyi apa yang kamu kenal dari namamu? Lalu anak mulai mengindentifikasi bunyi dan huruf seperti a dan ni (n dan i). jadi anak belajar dari konsep menyeluruh menuju ke parsial (Sit, 2017).

Penelitian ini diharapkan dapat bermanfaat: Bagi siswa, dengan aplikasi permainan menguraikan kata dapat meningkatkan kemampuan anak mengenal huruf. Bagi sekolah, Sebagai suatu alternatif untuk meningkatkan kualitas pada pembelajaran berbahasa anak Bagi guru, Media permainan menguraikan kata dapat diterapkan sebagai salah satu bentuk pembelajaran yang dapat meningkatkan pengenalan huruf dan menjadikan proses belajar lebih menarik. Bagi peneliti sendiri,Untuk mengembangkan ide-ide dan karya inovatif peneliti serta menambah wawasan dan pengetahuan melalui kegiatan pembelajaran terutama dalam meningkatkan kemampuan berbahasa anak.

\section{METHODOLOGY}

Metode penelitian pada dasarnya yang dipergunakan untuk memecahkan masalah penelitian. Penelitian yang penulis gunakan adalah penelitian tindakan kelas. PTK adalah suatu bentuk kajian yang bersifat reflektif, yang dilakukan oleh pelaku tindakan untuk meningkatkan kemantapan rasional (Srianis et al., 2014). Penelitian tindakan kelas ini dilakukan untuk memperbaiki dan meningkatkan kualitas pembelajaran yang dilakukan oleh guru dan bagi penulis sendiri untuk memperoleh hasil belajar yang baik serta memuaskan. Subjek dalam penelitian ini adalah anak-anak kelompok B1 Taman Kanak-kanak Islam Terpadu Bina Anak Sholeh Yogyakarta. Dengan jumlah murid 21 orang, anak laki-laki 8 orang dan anak perempuan 13 orang.

Penelitian ini akan dilakukan secara bersiklus, yang dimulai dari kondisi awal kemudian siklus pertama dan lanjut siklus kedua dengan Prosedur dari penelitian yang akan peneliti lakukan terdiri empat tahap penting Penelitian tindakan kelas adalah: a) perencanaan, b) pelaksanaan, c) pengamatan, d) refleksi (Sanjaya, 2016). Jika dalam siklus I belum berhasil dan meningkat, peneliti akan melakukan perbaikan kegiatan pembelajaran berdasarkan hal-hal yang belum dicapai pada siklus I. Pada siklus II ini akan dilakukan sama dengan siklus I yaitu perencanaan, pelaksanaan, pengamatan, dan refleksi. Dalam penelitian ini data dikumpulkan melalui teknik observasi dan dokumentasi. Data dianalisis dalam persentase dengan mengunakan rumus sebagai berikut :

$$
P=\frac{F}{N} \times 100 \%
$$




\author{
Keterangan : \\ $\mathrm{P}=$ Persentase aktivitas \\ $\mathrm{F}=$ Frekuensi aktivitas yang dilakukan anak \\ $\mathrm{N}=$ Jumlah anak dalam suatu kelas
}

\title{
RESULTS AND DISCUSSION
}

Berdasarkan hasil penelitian yang diperoleh dari pelaksanaan tindakan pada siklus I dan II pada kemampuan anak membaca mengenal huruf terjadi peningkatan mulai dari kondisi awal, Siklus 1dan Siklus II. Untuk lebih jelasnya dapat dilihat pada tabel dan grafik dibawah ini bahwa peningkatan kemampuan anak mengenal huruf di Taman Kanak-kanak Islam Terpadu Bina Anak Sholeh Yogyakarta Pada Kondisi Awal, Siklus I dan Siklus II (nilai sangat tinggi dan tinggi).

Tabel 1. Hasil Observasi

\begin{tabular}{|c|c|c|c|c|c|}
\hline No & Aspek yang diamati & $\begin{array}{c}\text { Kondisi } \\
\text { Awal }\end{array}$ & Siklus I & Siklus II & Keterangan \\
\hline \multirow[t]{3}{*}{1} & Anak mampu & 8 & 12 & 20 & \multirow{3}{*}{ Meningkat } \\
\hline & membaca gambar & & & & \\
\hline & $\%$ & 38 & 62 & 95 & \\
\hline \multirow[t]{3}{*}{2} & Anak mampu membaca & 7 & 12 & 20 & \multirow{3}{*}{ Meningkat } \\
\hline & kata pada Gambar & & & & \\
\hline & $\%$ & 33 & 62 & 90 & \\
\hline \multirow[t]{3}{*}{3} & Anak mampu & 5 & 11 & 19 & \multirow{3}{*}{ Meningkat } \\
\hline & menguraikan kata & . & & & \\
\hline & $\%$ & 24 & 53 & 91 & \\
\hline \multirow[t]{3}{*}{4} & Anak mampu & 7 & 12 & 20 & \multirow{3}{*}{ Meningkat } \\
\hline & $\begin{array}{l}\text { menyebutkan huruf } \\
\text { vocal pada kata }\end{array}$ & & & & \\
\hline & $\%$ & 33 & 62 & 95 & \\
\hline \multirow[t]{3}{*}{5} & Anak mampu & 7 & 13 & 19 & \multirow{3}{*}{ Meningkat } \\
\hline & $\begin{array}{l}\text { menyebutkan huruf } \\
\text { konsonan pada kata }\end{array}$ & & & & \\
\hline & $\%$ & 33 & 62 & 91 & \\
\hline \multirow[t]{2}{*}{6} & $\begin{array}{l}\text { Anak mampu } \\
\text { menyebutkan kata yang } \\
\text { mempunyai huruf awal } \\
\text { yang sam a }\end{array}$ & 6 & 13 & 19 & \multirow[t]{2}{*}{ Meningkat } \\
\hline & $\%$ & 29 & 62 & 91 & \\
\hline
\end{tabular}

Untuk lebih jelasnya dapat kita lihat dalam grafik sebagai berikut :

Gambar 1. Grafik Siklus 


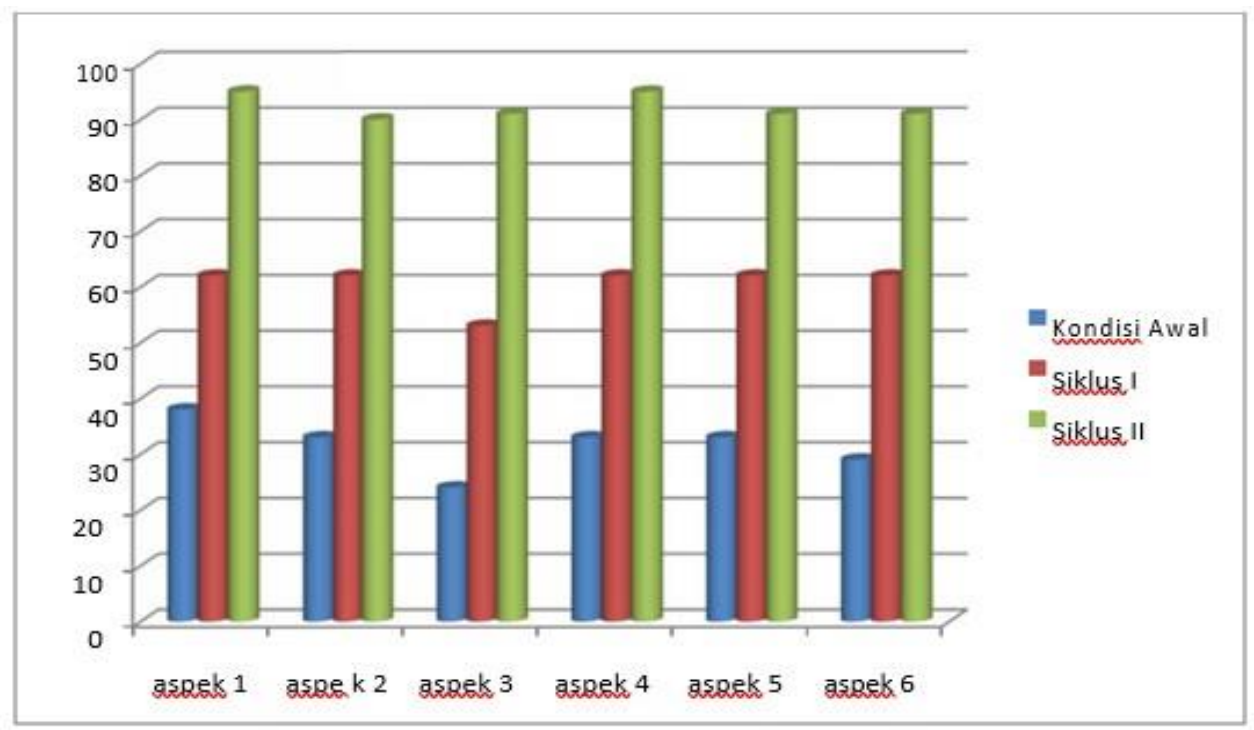

Berdasarkan hasil tabel dan grafik hasil observasi mulai dari kondsi awal, Siklus I dan Siklus II,dapat kita liha $\mathrm{t}$ peningkatan dalam beberapa aspek penin gkatan kemampuan pengenalan huruf melalui permainan menguraikan kata yaitu:

Aspek 1 anak mampu membaca gambar, pada kondisi awal adalah $38 \%$, pada siklus I menjadi $62 \%$ dan siklus I I meningkat menjadi $95 \%$. Persentase peningkatan dari kondisi awal pada siklus satu yaitu $24 \%$ dan dari siklus I kepada siklus II yaitu naik 33\%.Aspek 2 anak mampu membaca kat a pada gambar, pada kondisi awal adalah 3 Peningkatan dari kondisi awal pada siklus sattu yaitu 24\% dan dari siklus I kepada siklus II yaitu naik 33\%. Persentase peningkatan darii kondisi awal kepada siklus satu yaitu $24 \%$ dan dari siklus I kepada siklus II yaitu naik $38 \%$. Aspek 3 anak mampu menguraikan kata, pada kondisi awal adalah $24 \%$, pada siklus I menjadi $53 \%$ dan siklus II meningkat menjadi $91 \%$. Persentase penigkatan dari kondisi awal sampai siklus I yaitu $29 \%$, dan dari siklus I sampai siklus II naik menjadi $38 \%$. Aspek 4 anak mampu menyebutkan huruf vocal pada kata, pada kondisi awal adalah $33 \%$, pada siklus I menjadi 57\% dan siklus II meningkat menjadi 95\%. Persentase peningkatan dari kondisi awal kepada siklus satu yaitu $24 \%$ dan dari siklus I kepada siklus II yaitu naik $38 \%$. Aspek 5 anak mampu menyebutkan huruf konsonan pada kata, pada kondisi awal adalah 33\%, pada siklus I menjadi $62 \%$ dan siklus II meningkat menjadi $90 \%$. Persentase peningkatan dari kondisi awal kepada siklus satu yaitu 29\% dan dari siklus I kepada siklus II yaitu naik 28\%. Aspek 6 anak mampu menyebutkan kata yang mempunyai huruf awal yang sama, pada kondisi awal adalah $29 \%$, pada siklus I menjadi $62 \%$ dan siklus II meningkat menjadi $91 \%$. Persentase peningkatan dari kondisi awal kepada siklus satu yaitu 33\% dan dari siklus I kepada siklus II yaitu naik $29 \%$.

Pada kondisi awal tergambar kemampuan anak mengenal huruf masih rendah. Sebagian besar anak kelompok B I di Taman Kanak-kanak Islam Terpadu Bina Anak Sholeh masih banyak yang belum mengenal huruf, membedakan dan menyebut bunyi huruf. Jika diamati lebih lanjut hal ini disebabkan karena penerapan metode yang kurang tepat, minimnya pemanfaatan media, alat peraga dan kegiatan bermain. Berdasarkan kondisi awal ini, peneliti melakukan tindakan dengan menerapkan 
permainan menguraikan kata untuk meningkatkan kemampuan anak mengenal huruf.

Menurut Sudono alat permainan adalah sebuah alat bermain yang digunakan anak untuk memenuhi naluri bermainnya, Sudono juga mengatakan bahwa alat permainan adalah semua benda yang digunakan anak dalam kegiatan belajar mengajar dapat secara teratur, lancar, efektif, dan efisien, sehingga pendidikan Taman-kanak dapa tercapai. Menurut Tanaka dalam Sudono menyatakan bahwa alat permainan yang tujuan pengunaannya dipersiapkan harus bervariasi. Dengan adanya alat permainan yang bervariasi anak akan lebih terlatih dan merasa sangat senang (Sudono, 1995). Menurut abdul Permainan merupakan kesibukan yang dipilih sendiri tanpa ada unsur paksaan, tanpa didesak oleh rasa tanggung jawab (Khobir, 2009). Menurut Andayani Bermain adalah merupakan kegiatan yang spontan dilakukan oleh anak (Andayani, 2021).

Berdasarkan pendapat para ahli diatas dapat disimpulkan bahwa alat permainan adalah sebuah alat yang digunakan anak untuk memenuhi naluri bermain yang pengunaannya dipersiapkan harus bervariasi agar anak merasa senang dalam kegiatan pembelajaran.

Pada tindakan penelitian siklus I kegiatan pembelajaran telah menggunakan media berupa kartu gambar yang ada kata nama dari gambar, kartu suku kata, kartu huruf dan kartu gambar yang ada kata dari nama gambar yang dipenggal katanya menjadi suku kata. Dari tindakan siklus I terlihat peningkatan kemampuan untuk setiap aspek yangdiamati namun peningkatannya masih belum stabil dan belum mencapai KKM yaitu 75\%, karena masih ada anak yang masih belum bisa mengenal huruf. Maka penelitian dilanjutkan pada siklus II.

Pada siklus II peneliti melakukan pembelajaran yang lebih memotivasi anak dengan manambah kartu huruf, kartu suku kata yang diwarnai tiap hurufnya dan gambar yang menarik bagi anak. Berdasarkan tindakan yang telah dilakukan dapat dijabarkan keberhasilan pengunaan permainan menguraikan kata sebagai berikut:

Aspek 1 anak mampu membaca gambar, pada kondisi awal adalah 38\%, pada siklus I menjadi 62\% dan siklus II meningkat menjadi 95\%. Aspek 2 anak mampu membaca kata pada gambar, pada kondisi awal adalah 33\%, pada siklus I menjadi 57\% dan siklus II meningkat menjadi 95\%. Aspek 3 anak mampu menguraikan kata, pada kondisi awal adalah $24 \%$, pada siklus I menjadi $53 \%$ dan siklus II meningkat menjadi 91\%. Aspek 4 anak mampu menyebutkan huruf vocal pada kata, pada kondisi awal adalah 33\%, pada siklus I menjadi 57\% dan siklus II meningkat menjadi 95\%. Aspek 5 anak mampu menyebutkan huruf konsonan pada kata, pada kondisi awal adalah 33\%, pada siklus I menjadi 62\% dan siklus II meningkat menjadi $90 \%$. Aspek 6 anak mampu menyebutkan kata yang mempunyai huruf awal yang sama , pada kondisi awal adalah $29 \%$, pada siklus I menjadi $62 \%$ dan siklus II meningkat menjadi $91 \%$.

Berdasarkan hasil dari uraian diatas dapat jelaskan dimana untuk setiap aspek yang jumlah persentase keberhasilan bisa melampau batas minimum KKM yaitu 75\%. Hal ini menunjukan bahwa penelitian ini berhasil.

\section{CONCLUSION}


Kemampuan anak mengenal huruf di Taman Kanak-kanak Islam Terpadu masih rendah, untuk memotivasi dan meningkatkan rendahnya kemampuan anak dalam mengenal huruf maka dilakukan tindakan melalui permainan menguraikan kata. Bermain merupakan cara yang paling baik untuk mengembangkan potensi yang ada pada anak. melalui bermain, anak akan memperoleh pengetahuan dan keterampilan, permainan menguraikan kata dengan media kartu gambar yang bertuliskan nama dari gambar, kartu gambar yang ada nama gambar yang dipenggal kata menjadi suku kata dan kartu huruf. Kartu suku kata akan dapat meningkatkan kemampuan anak mengenal huruf dan membaca pada anak, dengan adanya peningkatan persentase dari siklus I ke siklus II, kemampuan membaca anak mengenal huruf dapat meningkat dengan mengunakan permainan menguraikan kata kelompok B TKIT Bina Anak Sholeh (BIAS) Yogyakarta. Pelaksanaan permainan menguraikan kata dapat meningkatkan kemampuan membaca anak terutama dalam pengenalan huruf vokal dan konsonan pada anak, pelaksanaan permainan menguraikan kata, kartu gambar yang bertuliskan kata nama dari gambar dapat meningkatkan kemampuan anak dalam menyebutkan kata yang mempunyai huruf awal yang sama seperti bola, baju dan lain sebagainya.

\section{REFERENCES}

Andayani, S. (2021). Bermain sebagai sarana pengembangan kreativitas anak usia dini. JURNAL AN-NUR: Kajian Ilmu-Ilmu Pendidikan Dan Keislaman, 7(1), 230-238.

Ardyatmika, I. A. I. A., Parmiti, D. P., Ujianti, P. R., \& Psi, S. (2016). Penerapan Metode Bermain Melalui Media Playdough Untuk Meningkatkan Kemampuan Motorik Halus Anak Kelompok A Semester Ii Di Tk Widya Kumarasthana Tahun Ajaran 2015/2016. Jurnal Pendidikan Anak Usia Dini Undiksha, 4(2).

Astria, N., Made Sulastri, M. P., \& Magta, M. (2015). Penerapan Metode Bermain Melalui Kegiatan Finger Painting untuk Meningkatkan Kemampuan Motorik Halus. Jurnal Pendidikan Anak Usia Dini Undiksha, 3(1).

Depdiknas. (1995). Metodik khusus Pengembangan Bahasa.

Depdiknas. (2000a). Metode Pengembangan Kemampuan Berbahasa.

Depdiknas. (2000b). Metode Permainan membaca dan menulis.

Fauzia, H. A. (2018). Penerapan Model Pembelajaran Problem Based Learning Untuk Meningkatkan Hasil Belajar Matematika SD. Primary: Jurnal Pendidikan Guru Sekolah Dasar, 7(1), 40-47.

Khobir, A. (2009). Upaya mendidik anak melalui permainan edukatif. Forum Tarbiyah, 7(2), 197-208.

Muliawan. (2009). Management Play group dan TK. Diva Pres.

Purnamasari, N. K. N., Negara, I. G. A. O., Ke, S. P. M., \& Suara, I. M. (2014). Penerapan Metode Demonstrasi Melalui Kegiatan Melipat Kertas (Origami) Untuk Meningkatkan Perkembangan Motorik Halus Anak Tk Kemala 
Bhayangkari 1 Denpasar. Jurnal Pendidikan Anak Usia Dini Undiksha, 2(1), 1-10.

Rohim, F., \& Susanto, H. (2012). Penerapan model discovery terbimbing pada pembelajaran fisika untuk meningkatkan kemampuan berpikir kreatif. UPEJ Unnes Physics Education Journal, 1(1).

Sanjaya, D. R. H. W. (2016). Penelitian tindakan kelas. Prenada Media.

Siska, Y. (2011). Penerapan metode bermain peran (role playing) dalam meningkatkan keterampilan sosial dan keterampilan berbicara anak usia dini. J. Educ, 1(1), 31-37.

Sit, M. (2017). Psikologi Perkembangan Anak Usia Dini Edisi Pertama. Kencana.

Srianis, K., Suarni, N. K., Ujianti, P. R., \& Psi, S. (2014). Penerapan metode bermain puzzle geometri untuk meningkatkan perkembangan kognitif anak dalam mengenal bentuk. Jurnal Pendidikan Anak Usia Dini Undiksha, 2(1).

Sudono, A. (1995). Alat Permainan dan Sumber Belajar TK. In Jakarta: Departemen Pendidikan dan Kebudayaan, Direktorat Jendral Pendidikan Tinggi Proyek Pendidikan Tenaga Akademik. 